\title{
Do European banks manipulate risk weights?
}

\author{
This version: May 2018
}

\begin{abstract}
Exploiting the information provided by the 2014 Comprehensive Assessment of the European Central Bank and the European Banking Authority, we provide new evidence on the manipulation of risk weights by banks. Concentrating our attention on credit risk density (non-defaulted risk weighted loans over non-defaulted loans), we confirm that the internal rate based approach (mostly the advanced) is used by banks to manipulate risk weights. Moreover, we find that risk weights are mostly underestimated in case of loans in the domestic market and in case of loans to the corporate and retail sectors-i.e. when asymmetric information is significant. We also show that the attitude to underestimation of risk weights is not due to incorrect assumptions of banks' models. Our evidence supports the hypothesis that national supervisory authorities are captured by local banks.
\end{abstract}

Keywords: bank regulation, risk weight, Basel II, European Central Bank

JEL codes: E58, E65, G21, G28 


\section{Introduction}

The answer to the question posed in the title is yes, and it doesn't come as a surprise.

The financial crisis showed that regulation of the banking sector and its supervision were not able to prevent a systemic financial crisis. Two main lessons can be learned: the Basel micro-prudential approach based on risk weighted capital ratios is not able to guarantee the solidity of a bank standalone; and the classical supervisory approach is not well suited to cope with systemic risk. In this paper, we provide new insights into the first issue. Exploiting the information provided by the 2014 Comprehensive Assessment (CA) of the European Central Bank (ECB) and the European Banking Authority (EBA), we provide new evidence on manipulation of risk weights by banks. Concentrating our attention on credit risk density (non-defaulted risk weighted loans over nondefaulted loans), we confirm that the internal rate based (IRB) approach is used by banks to manipulate risk weights. Furthermore, we find that risk weights are mostly underestimated in case of loans to the corporate and the retail sectors and in case of loans in the domestic market, highlighting the possibility of a benevolent approach by the supervisory authority towards domestic banks.

The debate generated from the financial crisis highlighted that the classical risk weighted capital ratio was not a good/exhaustive indicator of financial solidity-see, for example, Laeven and Valencia (2010), European Banking Authority (2011) and Haldane (2012). Several contributions showed that a high risk weighted capital ratio was not correlated with the solidity of the bank (e.g. default, state aids or bail out); in particular, bank soundness was much more related to the leverage ratio than to the Tier 1 capital ratio. Scepticism was reinforced by the fact that the large variation observed in risk weighted assets was not driven by banks' business models and risk profiles: there is room for supervisory and managerial practices (see Haldane 2011; Cannata et al. 2012; Le Leslé and Avramova 2012; Basel Committee on Banking Supervision 2013a, 2013b; European Banking Authority 2013). There is also evidence showing that banks use the discretion of Basel II agreements (mostly the internal rate based approach) to reduce the risk weighted assets (see Beltratti and Paladino 2013; Vallascas and Hagendorff 2013; Behn et al. 2014; Mariathasan and Merrouche 2014). According to this interpretation, banks exploit the flexibility of the Basel II internal model to underestimate their risks (see also Das and Sy 2012; Le Leslé and Avramova 
2012). Note that the Basel III system allows for country-specific discretionary measures during the "phase-in period": this may introduce a further 'manipulation' at the country level (Visco 2014).

The above analysis is mostly descriptive/qualitative. In what follows, we adopt a more structured approach and we investigate the possibility of risk weight manipulation, controlling for several factors including portfolio riskiness, risk attitude, and business specialization. Our starting point is the analysis by Mariathasan and Merrouche (2014), who analyse a sample of 115 OECD banks during 2007-2010. They concentrate their attention on the effect of the adoption of the IRB model, analysing the risk density of a bank before and after the adoption of the internal model. After the adoption of the IRB model, they observe a reduction which may refer to four different hypotheses: portfolio reallocation (towards safer assets); improved risk measurement (more refined risk weights); faulty risk modelling; and risk weight manipulation (regulatory arbitrage). Due to the limitations of the data set and of the pre-post analysis, they are not able to completely disentangle the different hypotheses. They conclude that there is evidence of risk modelling mistakes and of regulatory arbitrage. Behn et al. (2014) also provide evidence of risk manipulation through IRB models by German banks: probability of defaults and risk weights are significantly lower for portfolios managed through the IRB approach compared with portfolios handled through the standardized approach, while ex-post default rates go in the opposite direction. Barakova and Palvia (2014) provide different evidence showing that the risk weights computed according to an advanced IRB model by US banks are highly correlated with the loan performance, and conclude that risk weights are not largely driven by non-risk base factors.

Differently from Mariathasan and Merrouche (2014), we concentrate our attention on the risk density of the credit activity. This allows us a more refined analysis; for example, we control adequately for portfolio reallocation and business models that may drive the risk density, as suggested in Cannata et al. (2012). Another important point is that our analysis consists of a static cross-section analysis of 2013 balance sheet data that are far enough from the financial crisis, whereas the above analysis refers to turbulent years and the time dimension may introduce a bias due to the procyclicality in the measurement of risk weights (Cannata et al. 2012). Furthermore, banks could have reduced portfolio risks (de-risking) in the more turbulent period as an immediate response to the crisis. Moreover, by restricting our attention to European banks, we control for the accounting regimes that may affect the analysis when the sample includes US and European banks (Cannata et al. 2012; Le Leslé and Avramova 2012). 
Our main results show that the IRB approach is used by banks to manipulate risk weights and that risk weights are mostly underestimated in case of loans in the domestic market and in case of loans to the corporate and retail sectors rather than to the institutional sector.

The result for the domestic market suggests that risk manipulation may also be due to the weak role played by national supervisory authorities in relation to local banks. The fact that there is evidence of manipulation in case of loans to the corporate and the retail sector rather than to the institutional sector reinforces this interpretation, because the first two sectors are characterized by a higher degree of information asymmetry. Manipulation mainly occurs through the advanced rather than the foundation IRB approach. Finally, we find evidence that the attitude to underestimating riskiness is not due to incorrect assumptions of banks' models.

The paper is organized as follows. In Section 2, we present our data set and the empirical model. In Section 3, we present our main results. In Section 4, we provide a further analysis on business sectors, markets and supervision. Section 5 concludes.

\section{The data set and the empirical model}

We analyse bank level data using the dataset collected by the EBA and by the ECB during the CA in 2014 (see European Central Bank (2014) for the complete list of banks). ${ }^{1}$ Our sample is made up of 121 banks operating in the euro area (Table 1). Data at country level are 2013 values from the World Bank database.

We concentrate our attention on the risk density of the credit business. The risk density is defined as the ratio between non-defaulted risk weighted loans and the total (risk unweighted) nondefaulted credit exposure. The risk density of the credit business is a measure of non-defaulted loan riskiness evaluated by banks using the standard and/or the IRB approach. In order to explore the potential effect of bank counterparties, we consider three different customer segments: i) institutional (banks, insurance companies, pension funds, hedge funds); ii) corporate, which

\footnotetext{
${ }^{1}$ Unfortunately, the EBA and the ECB did not implement the CA before 2014, therefore we cannot compare our results with previous analyses, and in particular with pre-crisis evaluations. The 2014 CA was a unique event in Europe and was related to the change of the supervision from National Competent Authorities to the Single Supervisory Mechanism for the largest banks in the area.
} 
includes loans to firms with a total amount larger than $€ 1$ million; and iii) retail, which includes loans up to $€ 1$ million to small and medium firms (turnover or balance sheet up to $€ 50$ million) and to households (mortgages and other loans). Our choice of the risk density of the credit activity allows us to refine previous analyses. Limiting our attention to loans, we control for portfolio asset allocation (market/credit risk) that may affect the analysis. Taking into account the counterparty of the loans, we refine the analysis, addressing the business specialization of the bank, which is one of the main sources of risk density dispersion in the banking sector (Cannata et al. 2012).

We consider the bank's credit portfolio at country level. As shown in Table 1, the banks in our sample are active, on average, in 4.8 credit markets, including their domestic country, through their branches or subsidiaries. Taking into account the credit market, we consider a source of risk density interbank dispersion linked to the country and supervisory standards (Cannata et al. 2012; European Banking Authority 2013).

We estimate the following model: ${ }^{2}$

riskdensityBS $_{\mathrm{i}, \mathrm{c}}=\mathrm{k}+\gamma_{1} \cdot \operatorname{irbBS}_{\mathrm{i}, \mathrm{c}}+\gamma_{2} \cdot$ defrateBS $_{\mathrm{i}, \mathrm{c}}+\delta_{1} \cdot$ provision $_{\mathrm{i}}+\delta_{2} \cdot$ levratio $_{\mathrm{i}}+$

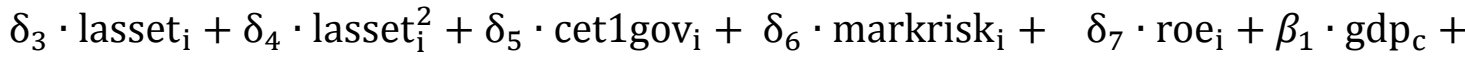

$$
\begin{aligned}
& \beta_{2} \cdot \text { marketcap }_{c}+\beta_{3} \cdot \text { capstring }_{c}+\beta_{4} \cdot \text { supind }_{c}+\beta_{5} \cdot \text { extaudit }_{c}+\rho \cdot \text { Ddom }_{i, c}+\varepsilon_{i, c}
\end{aligned}
$$

where the dependent variable, riskdensityBS, is the risk density for non-defaulted loans in the business sector $B S$ for bank $i$ operating in country $c{ }^{3}$ The business sectors $(B S)$ considered in our analysis are institutional (INST), corporate (COR) and retail (RET), as well as three sectors together $(A L L)$. We include two types of exogenous variables: bank-specific variables (lower case $i$; $\delta$ coefficients) and country-specific variables (lower case $c ; \beta$ coefficients)-that refer to the country in which the bank operates. Definitions and descriptive statistics of all the variables used in the empirical analysis are reported in Table 2.

Our main goal is to test the use of the IRB model to manipulate the risk weights. The relevance of an IRB model is captured through the variable irbALL, which is provided by the ratio between credit

\footnotetext{
${ }^{2}$ The correlation matrix for the exogenous variables is reported in Table 3, part B.

${ }^{3}$ We also considered as a dependent variable the risk density based on the overall credit portfolio and not only on nondefaulted loans. Results are robust for this test and are available upon request.
} 
exposure evaluated according to an IRB approach (foundation or advanced) and the overall exposure (both numerator and denominator are risk unweighted) for the overall credit portfolio (irbINST, irbCOR and irbRET respectively refer to the credit exposures with institutional, corporate and retail business sectors). A negative (positive) $\gamma_{1}$ may signal that risk weights are (over-) underestimated by using an IRB model. To derive this conclusion, a closer look at the issue is needed: an IRB may provide a better representation of the risks of the credit portfolio and therefore we should control for its riskiness.

To this end, we follow Barakova and Palvia (2014), considering two different measures of credit portfolio risk/performance:

- Default rate in the business sector BS (defrateBS), which is given by the ratio between defaulted loans and the sum of defaulted and non-defaulted loans. Note that both the numerator and the denominator are risk unweighted. This variable can be considered as an ex-ante proxy of the probability of default (PD) of the loan portfolio on which the numerator of the risk density is computed. An unbiased risk density for non-defaulted loans should reflect the PD computed according to the back book of defaulted loans; thus $\gamma_{2}$ should be positive. On the other hand, a statistically non-significant or a negative coefficient can be considered as evidence of a non-correct evaluation of risk weights.

- Ratio between impairment of non-financial assets and operating profits before impairment (provision). Past charge-offs represent an ex-post measure of risk for the past portfolio of credit exposure: high impairment signals that outstanding loans are riskier than expected. As a consequence, an unbiased risk density should be positively affected by provision, and a non-statistically significant or negative coefficient can be considered as evidence of manipulation of risk weights and managers' discretion on loan loss provisions. Note that the variable is computed for the complete balance sheet, at bank consolidated level, and not for the specific business sector and country where banks operate.

The attitude to optimize/manipulate risk weights through an IRB model depends on the risk attitude of banks' managers (moral hazard hypothesis). We consider three different proxies of risk attitude related to moral hazard based on capital/profitability measures:

- Leverage ratio (levratio), computed as CET1 capital over total assets and measured according to the Capital Requirements Regulation (CRR) under the Capital Requirements 
Directive (CRD). According to the banking capital regulation debate, banks with a lower non risk-adjusted capital ratio are likely to be more risk loving, mainly because they have a larger book (and often riskier assets) to boost profitability and are more exposed to bank runs (Rochet 1992; Blum 2008). Managers may have the incentive to leverage the bank in order to spread profits on a narrower equity base (Tarullo 2008). Actually, before the financial crisis, many banks adopted exactly this strategy (Haldane et al. 2010). According to this interpretation, managers of a leveraged bank may also have an incentive to underestimate their risks to meet capital requirements. Consequently, we expect the effect of levratio on risk density to be positive.

- Ratio between CET1 capital instruments subscribed by the home state over total assets (cet1gov). This variable measures the extent of state aids after the financial crisis. State aids could induce a moral hazard effect. As a matter of fact, managers may be tempted to take risks in excess and to manipulate risk weights because they are under the umbrella of the state (Gropp et al. 2010; Duchin and Sosyura 2011; Dam and Koetter 2012; Mariathasan et al. 2014). Thus, the effect of cet1gov on risk density should be negative.

- The return on equity (roe). Profitability measured with respect to capital is a proxy of risk (European Central Bank 2010). As a consequence, the risk density may be negatively affected by roe. Note that Beltratti and Paladino (2013) showed that risk weight optimization is positively affected by the cost of equity.

We control for the bank balance sheet considering two variables:

- The share of market risks over risk weighted assets (markrisk). Considering the risk density only of the credit activity, we address the weaknesses of previous studies on risk weight manipulation that consider the risk density of the balance sheet as a whole, which is affected by the heterogeneity of balance sheet composition (Cannata et al. 2012; Mariathasan and Merrouche 2014). To capture the possibility of a business mix effect, we consider the quota of market risk.

- As an indicator of bank size, we consider the logarithm of total assets (lasset); we allow for nonlinearities by including the square of the variable (lasset $\left.{ }^{2}\right)$. The relationship between risk density and size is unclear. The attitude of the supervisory authority towards a bank may depend on its size for several reasons: on the one hand, a large bank is more likely to be supervised by the market and the supervisory authority is more likely to be captured by a 
large bank, and therefore the supervisory activity by the authority could be less intense; on the other hand, a larger bank is riskier from a systemic risk perspective, thus potentially making supervision tougher.

In our analysis, we control for country-specific variables:

- The real GDP growth rate of the bank home country $(g d p)$. GDP growth, influencing economic conditions and therefore the quality of credit, should imply a lower risk density. ${ }^{4}$

- An indicator of capital requirement stringency elaborated by the World Bank (capstring). This index ranges from 0 to 7 , where higher values indicate greater stringency of the capital requirements in capturing risk factors and in deducting certain market value losses to determine regulatory capital. ${ }^{5}$ A positive effect of capstring may signal the effectiveness of the regulation, while a negative coefficient may support the risk weight manipulation hypothesis: if this is the case, then we can infer that banks react to stricter requirements on capital by reducing risk weights.

- An indicator of the independence of the supervisory authority elaborated by the World Bank (supind). This index ranges from 0 to 3, where higher values indicate greater independence from governments and stronger legal protection from banking industries. ${ }^{6}$ Our hypothesis is that an independent supervisory authority should be less prone to accept a lower risk density; as a consequence, we expect the coefficient of supind to be positive.

- As in Mariathasan and Merrouche (2014), we consider an index for the strength of external audits elaborated by the World Bank (extaudit). This index ranges from 0 to 7 , where higher

\footnotetext{
${ }^{4}$ As an alternative measure of economic conditions, we considered the growth rate of domestic loans, between 2006 (pre-crisis period) and 2013, in each country (source ECB). The main results are confirmed in this specification.

${ }^{5}$ The index is based on answers to the following questions: 1) Which regulatory capital adequacy regimes did you use as of the end of 2010 and to which banks does each regime apply?-a) Basel I; b) Basel II; c) leverage ratio; d) other; 2) Which risks are covered by the current regulatory minimum capital requirements in your jurisdiction?-a) credit risk; b) market risk; c) operational risk; d) other risks; 3) Are the following items deducted from regulatory capital?-a) goodwill; b) deferred tax assets; c) intangibles; d) unrealized losses in fair valued exposures; e) investment in the capital of certain banking, financial and insurance entities which are outside the scope of consolidation; 4) What fraction of revaluation gains is allowed as part of capital?

${ }^{6}$ The index is based on answers to the following questions: 1) To whom is the supervisory agency legally responsible or accountable?-a) a legislative body, such as Parliament or Congress; b) the head of government (e.g. President, Prime Minister); c) the Finance Minister or other cabinet level official; d) other; 2) Can individual supervisory staff be held personally liable for damages to a bank caused by their actions or omissions committed in the good faith exercise of their duties? 3) Does the head of the supervisory agency have a fixed term? If yes, how long (in years) is the term?
} 
values indicate a stronger external audits of banks. ${ }^{7}$ More effective audits should increase balance sheet transparency/risk reporting; thus we expect a positive effect from extaudit.

- An index of the degree to which actions are taken by regulators to mitigate bank moral hazard elaborated by the World Bank (moralhaz). The index takes values between 0 and 3. Higher values indicate greater mitigation of moral hazard and therefore this variable should have a positive effect on risk density. ${ }^{8}$

Finally, we include the dummy variable Ddom, which is equal to 1 for the home country credit portfolio and 0 for the cross-border credit portfolios. Through Ddom, it is possible to test whether the risk density is affected by the fact that the bank operates in the home country or abroad. As we already control for portfolio risks, a negative value of the coefficient of this variable may signal that supervisory authorities are mild with domestic banks and severe with foreign banks.

\section{Empirical analysis}

We estimate equation (1) considering the risk density for the three sectors together (riskdensityALL) using both fixed and random effect estimators, with robust standard errors clustered at bank level. ${ }^{9}$ Our strategy is first to estimate a reduced model including only irbALL and defrateALL as well as bank and country fixed effects, and then to consider bank- and countryspecific variables.

We find that the defrateALL coefficient is positive and significant. Coherently with the regulatory approach, the risk density for the overall portfolio of non-defaulted loans is positively affected by

\footnotetext{
${ }^{7}$ The index is based on answers to the following questions: 1) Is an audit by a professional external auditor required for all commercial banks in your jurisdiction? 2) Are specific requirements for the extent or nature of the audit spelled out? 3) Do supervisors receive a copy of the following? - a) the auditor's report on the financial statements; b) the auditor's letter to bank management; c) other communication to the audit committee; 4) Does the banking supervisor have the right to meet with the external auditors and discuss their report without the approval of the bank? 5) Are auditors required to communicate directly to the supervisory agency any presumed involvement of bank directors or senior managers in illicit activities, fraud or insider abuse? 6) In cases where the supervisor identifies that the bank has received an inadequate audit, does the supervisor have the powers to take actions against: a) the external auditor; $b$ ) the bank?

${ }^{8}$ The index is based on answers to the following questions: 1) Funding is provided by: a) Government; b) banks; c) combination/other; 2) Do deposit insurance fees/premiums charged to banks vary based on some assessment of risk? 3 ) Is there formal coinsurance-i.e. are all depositors explicitly insured for less than $100 \%$ of their deposits?

${ }^{9}$ As a robustness test, we consider as our data set only bank data at consolidated level. Consequently, the observations drop to 99 data. Main results are robust to this test and are available upon request.
} 
the historical default rate (Barakova and Palvia 2014). In line with Mariathasan and Merrouche (2014) and Behn, Haselmann, and Vig (2014), we find that irbALL has a negative and highly significant impact on risk density. We interpret this result as evidence of risk weight manipulation: a more intense use of an IRB approach allows managers to reduce the credit risk density. Having controlled for the credit riskiness, this effect cannot be attributed to a better selection of customers and/or to a more precise risk weight definition when IRB models are used.

In Table 4, model II, we include bank-specific variables, and as a consequence we drop the bank fixed effects. Results for irbALL and defrateALL are robust to the inclusion of these control variables. ${ }^{10}$ The possibility of risk weight manipulation is confirmed by the observation that banks operating in their home countries are characterized by a lower credit risk density, as the negative and statistically significant coefficient of Ddom shows. This result may signal an information competitive advantage for domestic banks in terms of credit activity. This interpretation is not convincing, as we have already controlled for default probability: it is more likely that national supervisory authorities are less rigorous towards domestic banks in the definition of risk weights and in the validation of internal models. We will come back to this point in the next section.

In Table 4, model III, we also include the country-specific variables. Results for irbALL, defrateALL and Ddom are robust to the inclusion of the complete set of control variables. ${ }^{11}$ The possibility of risk weight manipulation is confirmed by the analysis of the effect of regulation and of the effectiveness of supervision. We expect stricter rules and weaker supervision to negatively affect the risk density. Confirming this interpretation, the indicator of capital requirement stringency (capstring) has a negative and significant effect on credit risk density. It seems that banks react to stringent capital rules by decreasing risk weights. On the other hand, stronger external audit of banks (extaudit) and more effective actions to mitigate moral hazard by the supervisor (moralhaz)

\footnotetext{
${ }^{10}$ Among bank-specific variables, we find that the coefficient related to provisions is positive and significant (Barakova and Palvia 2014). Risk density and bank size have a U-reverse shaped relationship: small and large banks appear to be less risky than medium banks. However, these two outcomes should be considered with caution because they are not robust to different econometric specifications.

${ }^{11}$ As far as the leverage ratio is concerned, we find a positive and significant effect on the risk density in model III, Table 4. It seems that banks with higher non risk-adjusted capital ratios (less leveraged) are less risky. This outcome is in line with the moral hazard hypothesis: a manager of a non-leveraged bank is risk averse and therefore he is less inclined to manipulate risk weights. Moreover, we find that markrisk appears to have a positive and significant effect on the risk density.
} 
have a positive and significant effect on risk density, inducing a higher disclosure of actual bank riskiness. Only the variable supind on the independency of supervision plays no role.

In Table 4, model IV, we test whether the choice of the IRB approach has an impact on credit risk density. To address this issue, we consider two explanatory variables: irbadvALL and irbfounALL. As for irbALL, these variables are provided by the ratio between credit exposure, evaluated with an advanced or a foundation IRB approach respectively, and overall exposure (both numerator and denominator are risk unweighted). Looking at the effect of the IRB approach adopted, we may obtain further evidence on risk weight manipulation. As a matter of fact, advanced models are more suitable to manage risk weights than foundation ones. As a consequence, the coefficient associated with irbadvALL should be negative and larger in absolute value than that of irbfounALL.

Confirming this hypothesis, we find that a more intense use of an advanced IRB approach is associated with a negative and highly significant coefficient, while the irbfounALL coefficient has a lower magnitude and is not significant. ${ }^{12}$ The Wald test validates that the two coefficients are statistically different, showing that the negative impact on credit risk density for the overall portfolio is mainly driven by advanced IRB models. In line with Behn, Haselmann, and Vig (2014), we interpret this result as further evidence of risk weight manipulation. Moreover, our result seems to be in line with the analysis provided by the Basel Committee on Banking Supervision (2006), which shows that the adoption of an advanced IRB approach implies a higher reduction in minimum required capital than in the case of the foundation approach.

\section{Further results for business sectors, markets and supervision}

In this section, we test whether the effect of the adoption of IRB models depends on the type of counterparty, which is one of the main novelties of our analysis. Taking into account the econometric specification of Table 4, model IV, which includes the two variables for the advanced and the foundation IRB approach, we consider three different business sectors: i) corporate, ii) retail and iii) institutional. Analysing the three business sectors, we find evidence of non-reliability of risk weights for the institutional sector.

\footnotetext{
12 In Table 4, model IV, we do not include country-specific variables. In fact, comparing models II and III, we find that the $\mathrm{R}$-squared is higher when country-specific variables are not included, mainly due to the reduction in the number of observations. However, the main results are robust to the inclusion of country-specific variables.
} 
Estimates for corporate and retail sectors confirm previous results. We observe negative and highly significant coefficients both for the advanced and the foundation approach (models I and II, Table 5). Again, the magnitude of the advanced model is larger than for the foundation model and the Wald tests confirm that the coefficients are different. With respect to the institutional sector, we find that the coefficient of irbadvINST is negative but not significant, while irbfounINST is positive and significant (model III, Table 5). ${ }^{13}$ This result confirms the hypothesis that IRB models are used to manipulate risk weights, as the effect is statistically significant only in case of counterparties with higher information asymmetries (retail and corporate rather than institutional). The difference in the outcomes between institutional and corporate/retail loans may be traced back to the analysis made by the Basel Committee on Banking Supervision (2016), where it is shown that banks and other financial institutions (as well as large corporates-i.e. those with total assets exceeding €50 billion) are considered to be low-default exposures, and as a consequence PD and LGD estimations are not fully reliable.

Looking at the effect of the loan default rate in the different business sectors, we find support for this interpretation. The effect of the loan default rate is positive and significant only for the corporate and retail sectors (Table 5, models I and II), while is positive but not significant for the institutional sector (model III). A plausible explanation of this result is that external ratings from official rating agencies and market analyses are largely available for institutional exposures, yielding less accurate risk weights for these loans.

In Table 6, we further investigate the possibility of risk weight manipulation in three directions. ${ }^{14}$

Firstly, we consider the role of the domestic market. In model I, we interact defrateALL and irbALL with Ddom and (1-Ddom). Our goal is to evaluate the effect of the default rate and of the IRB's use intensity if the bank operates in its home country or abroad. We find that the credit risk density is more affected by the default rate when banks operate in a foreign market than in case of a domestic market, a result which seems to be in line with Basel Committee on Banking Supervision (2013a). In contrast, the irbALL coefficient is negative and significant only in cases where the bank

\footnotetext{
${ }^{13}$ Considering the econometric specification of Table 4, model III, we find that the irbINST coefficient is positive but not significant, while irbRET and irbCOR are negative and highly significant.

${ }^{14}$ To analyse the effectiveness of independent supervision, we include country-specific variables in the specifications, and as a consequence we drop country fixed effects.
} 
operates in the domestic market. ${ }^{15}$ These results provide further evidence that risk weight manipulation through the IRB approach mostly occurs in case of domestic activity and suggests that national supervisory authorities are captured by national (large) banks. It seems that banks are "allowed" by the supervisory authority to partially hide the risks of their domestic loan portfolio and to manipulate domestic risk weights by applying the IRB approach.

In model II, we further investigate the role of supervision in the manipulation of risk weights by interacting defrateALL and irbALL with a dummy variable that signals the level of supervisory independence from governments and legal protection from banking industries. More specifically, we introduce the dummy variable Dhsup, which is equal to 1 when the supind variable is equal to the maximum level (i.e. 3) and 0 otherwise. We find that the defrateALL coefficients are not statistically different when the independence of the supervisory authority is high or low, as shown by the Wald test. The interaction with irbALL shows that the coefficient is negative in both cases, but significant only when the independence of the supervisory authority is low. The Wald test shows that the coefficients are statistically different. This result supports the interpretation that supervisory authorities are captured by banks, as a matter of fact when they are not sufficiently independent from governments and legally protected from banking industries, the use of internal models allows banks to reduce the risk density significantly. Note that this result is in line with Huizinga and Laeven (2012) and Brown and Dinç (2011), who find that regulators could allow for non-compliance with accounting rules in order to prevent defaults of systemically important banks. It is worthwhile to observe that the national supervisor is in charge of validating the internal model. Note that the results obtained by estimating models I and II on the interaction of irbALL and defrateALL with Ddom and Dhsup allow us to exclude the hypothesis that the attitude to underestimating risks through IRB models is due to faulty risk modelling. As a matter of fact, model faultiness should be less present in the markets where the banks may use more refined information (domestic market) and should weakly depend on the degree of independence of supervision.

In Table 6, model III, we investigate how capital affects credit risk density by dividing banks on the basis of CET1 ratio distribution by country. More specifically, we build a dummy variable (Dhcet1) which is equal to 1 for those banks with a CET1 ratio larger than the third quartile of the domestic

\footnotetext{
${ }^{15}$ In both cases, the coefficients are statistically different, as pointed out by the Wald tests.
} 
market distribution and 0 otherwise. We then interact this variable with the defrateALL and irbALL variables. We find that the coefficient associated with the default rate is positive and significant only in case of non-well capitalized banks. With respect to the IRB variable, we find that the effect is negative and significant both for weak and well capitalized banks. However, the magnitude and significance are stronger in the case of well capitalized banks; the Wald test shows that coefficients are statistically different.

This evidence signals that banks with a higher ratio between common equity Tier 1 and risk weighted assets (CET1 ratio) are those that use the IRB model more intensely in order to manipulate credit risks. This evidence suggests that banks build capital buffers thanks to capital arbitrage (Vallascas and Hagendorff 2013). Note that our result is not in line with Mariathasan and Merrouche (2014), who find a significant negative relationship between IRB approval and reported riskiness for weak capitalized banks. ${ }^{16}$ The difference could be explained by the different time span considered. Mariathasan and Merrouche's (2014) database covers the period 2007-10, when the more stringent Basel III was not still implemented. Our result provides an explanation of the fact that well capitalized banks lobby for IRB and invest huge resources in developing these models. ${ }^{17}$ This result also agrees with the evidence showing that risk weighted capital ratios are not strictly correlated with the soundness of the banks (International Monetary Fund 2009; Hellwig 2010; Laeven and Valencia 2010; European Banking Authority 2011; Haldane 2012).

Finally, as robustness test we consider the possibility that some of the explanatory variables could be endogenous. In particular, we take into account that our main variable, i.e. the intensity of using IRB models, could be a function of the credit risk density. Higher levels of risk density could push bank managers to apply more sophisticated approaches in the underwriting procedures. Moreover, also leverage ratio, default rates and bank profitability could be affected by credit risk density. Thus, we apply a two-stage random-effect estimator, based on the Baltagi's (2008) implementation. Following Barth, Caprio and Levine (2002), we consider as instrumental variables, in addition to the other covariates, the following variables:

\footnotetext{
${ }^{16}$ As a robustness test, we also calculate our dummy, which signals weak/well capitalized banks, as done by Mariathasan and Merrouche (2014)-i.e. taking as a threshold the sample mean for the overall sample and the sample mean plus one standard deviation. Results are robust to this test and are available upon request.

${ }^{17}$ Aite Consulting Group (2007) estimates that US banks alone would spend \$800 million in 2007 in A-IRB models.
} 
- The legal tradition on financial development. We build a dummy variable which is equal to 1 if the country $c$, where the bank $i$ has its headquarter, applies one of the four different legal systems identified by La Porta, Lopezde-Silanes, Shleifer, and Vishny (1998): i) the English common law (DlegalUK), ii) the French civil code (DlegalFR), iii) the German civil code (DlegalGE) and iv) the Scandinavian civil code (DlegalSC); 0 otherwise. We use this variable as proxy of legal segmentation among European countries;

- The latitudinal distance from the equator of the country $c$ (distance), calculated as latitude divided by 90 (the maximum latitude corresponding to the North Pole). We take data on latitude from Google Earth. We use this variable as proxy of cultural distance among European countries;

- The percentage of Muslim population in the country $c$ (muslim). We use data from Pew Research Centre relative to 2010. We use this variable as a proxy of ethnic diversity among European countries.

To check whether the excluded instruments are valid instruments, which require that they are uncorrelated with the error term and are correctly excluded from the estimated equation, we report the Sargan-Hansen statistic. ${ }^{18}$

The estimation outputs of the instrumental variables approach, for the overall credit portfolio and for each of the business sectors considered previously, are reported in Table 7. The Sargan-Hansen statistics show the validity of the overidentifying restrictions in models (I)-(IV). We find that the main results on the intensity of using IRB models are robust to this test on the estimation method.

\section{Conclusions}

Exploiting information provided by the 2014 Comprehensive Assessment of the European Central Bank and the European Banking Authority, we provide new evidence on the manipulation of risk weights by banks. Concentrating our attention on credit risk density (non-defaulted risk weighted loans over non-defaulted loans) and on domestic-foreign markets, we refine previous analyses. We

\footnotetext{
${ }^{18}$ We do not use DlegalSC as instrumental variable to avoid perfect identification. In order to pass the Sargan-Hansen test, when considering the risk density for the corporate and institutional business sectors we do not include distance among instrumental variables.
} 
confirm that the internal rate based approach (mostly the advanced) allows underestimation of credit portfolio riskiness. This effect is due to manipulation of risk weights/capital arbitrage, while we find little evidence of model faultiness.

As a matter of fact, risk weights are mostly underestimated in the case of loans in the domestic market and in the case of loans to the corporate and retail sectors (when asymmetric information is significant). Moreover, there is evidence that banking nationalism plays an important role in allowing an opportunistic behaviour. In fact, national supervisory authorities seem to be captured by local banks that are allowed to reach higher Basel capital ratios through the IRB approach.

Our analysis provides some important policy implications. First of all, our analysis supports the extension of the new Basel regulation on the leverage ratio, which is not affected by risk weight manipulation. Unfortunately, this measure is not binding until 2018 and the minimum requirement, set to three per cent, is unsatisfactory: Admati and Hellwig (2013) propose a threshold on the leverage ratio between 20 and 30 per cent, while Calomiris (2013) suggests a 10 per cent threshold combined with other changes in prudential regulation in order to ensure that banks maintain adequate equity relative to risk. King (2016), the former governor of the Bank of England, proposes tout court to apply the simpler leverage ratio instead of the more sophisticated risk-weighted capital ratio.

The role of IRB models should be reconsidered. Basel II regulation incentivized investments in costly risk management systems (IRB models) that allowed to reduce the capital requirements (Tarullo 2008). This trend has increased systemic risks, because large banks appear to be better capitalized thanks to advanced IRB models, also evading the stricter Basel III requirements connected to the too-big-to-fail problem. Recent developments on regulation by the Basel committee on the Fundamental Review of the Trading Book and on operational risk signal that we go in the direction of reducing the incentives for the adoption of IRB models (Basel Committee on Banking Supervision 2015, 2016). According to our analysis on risk weight manipulation, this represents a good move.

Finally, providing evidence of a favour towards domestic banks, this paper suggests that the Single Supervisory Mechanism is a good step in order to reduce banking nationalism. Completing the European Banking Union, by introducing a financial backstop and a deposit insurance scheme for bank deposits in the euro area as suggested by the so-called Five Presidents' Report (European 
Commission, 2015), will improve financial stability in Europe by further reducing banking market segmentation. 


\section{References}

Admati, Anat, and Martin Hellwig. 2013. The Bankers' New Clothes: What's wrong with Banking and What to do about it. Princeton: Princeton University Press.

Aite Consulting Group. 2007. Basel II or Basel Who: Risk Management Initiatives in the U.S. Boston, MA: Aite Consulting Group.

Baltagi, Badi H. 2008. Econometric Analysis of Panel Data. 4th ed. New York: Wiley.

Barakova, Irina, and Ajay Palvia. 2014. “Do Banks' Internal Basel Risk Estimates Reflect Risk?" Journal of Financial Stability 13: 167-179.

Barth, James R., Gerard Caprio, Jr. and Ross Levine. 2002. "Bank Regulation and Supervision: What Works Best?" NBER Working Paper No. 9323.

Basel Committee on Banking Supervision. 2006. Results of the Fifth Quantitative Impact Study (QIS 5).

Basel Committee on Banking Supervision. 2013a. Regulatory Consistency Assessment Programme (RCAP): Analysis of Risk Weighted Assets for Credit Risk in the Banking Book.

Basel Committee on Banking Supervision. 2013b. Regulatory Consistency Assessment Programme (RCAP): Analysis of Risk Weighted Assets for Market Risk.

Basel Committee on Banking Supervision. 2015. Fundamental Review of the Trading Book: Interim Impact Analysis.

Basel Committee on Banking Supervision. 2016. Reducing Variation in Credit Risk Weighted Assets: Constraints on the Use of Internal Model Approaches. Consultative document.

Behn, Markus, Rainer Haselmann, and Vikrant Vig. 2014. The Limits of Model-based Regulation. Mimeo.

Beltratti, Andrea, and Giovanna Paladino. 2013. Why do Banks Optimize Risk Weights? The Relevance of the Cost of Equity Capital. Mimeo.

Blum, Jurg. 2008. "Why Basel II may need a Leverage Ratio Restriction?" Journal of Banking and Finance 32: 1699-1707.

Brown, Craig O., and I. Serdar Dinç. 2011. "Too Many to Fail? Evidence of Regulatory Forbearance when the Banking Sector is Weak." Review of Financial Studies 24 (4): 1378-1405.

Calomiris, Charles W. 2013. "Reforming banks without destroying their productivity and value." Journal of Applied Corporate Finance 25 (4): 14-20.

Cannata, Francesco, Simone Casellina, and Gregorio Guidi. 2012. Inside the Labyrinth of Basel Risk Weighted Assets: How Not to Get Lost. Bank of Italy, occasional paper nr. 132. 
Dam, Lammertjan, and Michael Koetter. 2012. "Bank Bailouts and Moral Hazard: Evidence from Germany." Review of Financial Studies 25: 2343-2380.

Das, Sonali, and Amadou Sy. 2012. How Risky are Banks' Risk Weighted Assets? Evidence from the Financial Crisis. IMF working paper.

Duchin, Ran, and Denis Sosyura. September 2011. Safer Ratios, Riskier Portfolios: Banks' Response to Government Aid. University of Michigan Ross School of Business Working Paper No. 1165.

European Banking Authority. 2011. "EBA Recommendation on the Creation and Supervisory Oversight of Temporary Capital Buffers to Restore Market Confidence." Accessed http://goo.gl/JiFoCT.

European Banking Authority. 2013. "Interim Results Update of the EBA Review of the Consistency of Risk Weighted Assets. http://goo.gl/leNuwX.

European Central Bank. 2010. Beyond ROE - how to measure bank performance, Appendix to the report on EU Banking structures, https://goo.gl/bDOO8K.

European Central Bank. 2014. "Institutions Included in the Comprehensive Assessment." http://goo.gl/HV7UPo.

European Commission. 2015. Completing Europe's Economic and Monetary Union. https://goo.gl/9LfuiQ.

Gropp, Reint, Hendrik Hakenes, and Isabel Schnabel. 2010. "Competition, Risk Shifting, and Public Bail-out Policies." Review of Financial Studies 24: 2084-2120.

Haldane, Andrew. 2011. Capital Discipline. Bank of England. Mimeo.

Haldane, Andrew. 2012. The Dog and the Frisbee. Bank of England. Mimeo.

Haldane, Andrew, Simon Brennan, and Vasileios Madouros. 2010. "What is the Contribution of the Financial Sector: Miracle or Mirage?" In The Future of Finance, LSE report, 87-120.

Hellwig, Martin F. 2010. "Capital Regulation after the Crisis: Business as Usual?" MPI Collective Goods Preprint 2010/31.

Huizinga, Harry, and Luc Laeven. 2012. "Bank Valuation and Accounting Discretion during a Financial Crisis." Journal of Financial Economics 106 (3): 614-634.

International Monetary Fund. 2009. Global Financial Stability Report, April 2009.

King, Mervyn. 2016. The end of alchemy: Money, banking, and the future of the global economy. WW Norton \& Company. 
La Porta, R., Lopez-de-Silanes, F., Shleifer, A., and Vishny, R. W. 1998. "Law and Finance," Journal of Political Economy, 106(6): 1113-1155.

Laeven, Luc, and F. Valencia. 2010. Resolution of Banking Crises: The Good, the Bad and the Ugly. IMF working paper 10/146.

Le Leslé, Vanessa, and Sofiya Avramova. 2012. Revisiting Risk Weighted Assets. IMF working paper, $12 / 90$.

Mariathasan, Mike, and Ourada Merrouche. 2014. "The Manipulation of Basel Risk Weights." Journal of Financial Intermediation 23: 300-321.

Mariathasan, Mike, Ouarda Merrouche, and Charlotte Werger. 2014. "Bailouts and Moral Hazard: How Implicit Government Guarantees affect Financial Stability." Mimeo.

Rochet, Jean-Charles. 1992. "Capital Requirements and the Behaviour of Commercial Banks." European Economic Review 36 (5): 1137-1170.

Tarullo, Daniel K. 2008. Banking on Basel: The Future of International Financial Regulation. Peterson Institute. Mimeo.

Vallascas, Francesco, and Jens Hagendorff. 2013. "The Risk Sensitivity of Capital Requirements: Evidence from an International Sample of Large Banks." Review of Finance 17: 1947-1988.

Visco, Ignazio. 2014. L'Attuazione dell'Unione Bancaria Europea e il Credito all'Economia. Audizione del Governatore della Banca d'Italia, Camera dei Deputati. 
Tables

Table 1. Sample by country

\begin{tabular}{lcc} 
Number of banks & $\begin{array}{c}\text { Average number of } \\
\text { credit markets } \\
\text { (domestic + foreigners) }\end{array}$ \\
\hline Austria & 6 & 8.0 \\
Belgium & 5 & 7.0 \\
Cyprus & 3 & 3.7 \\
Denmark & 4 & 4.0 \\
Finland & 1 & 6.0 \\
France & 11 & 5.0 \\
Germany & 24 & 7.3 \\
Greece & 4 & 4.0 \\
Hungary & 1 & 4.0 \\
Iceland & 3 & 4.0 \\
Italy & 15 & 2.4 \\
Latvia & 1 & 6.0 \\
Luxembourg & 2 & 8.5 \\
Malta & 1 & 5.0 \\
Netherlands & 6 & 5.0 \\
Norway & 1 & 9.0 \\
Poland & 6 & 1.3 \\
Portugal & 3 & 4.7 \\
Slovenia & 3 & 3.3 \\
Spain & 13 & 1.7 \\
Sweden & 4 & 7.0 \\
United Kingdom & 4 & 3.8 \\
\hline Total & $\mathbf{1 2 1}$ & $\mathbf{4 . 8}$ \\
Source: & &
\end{tabular}

Source: Authors' computation 
Table 2. Summary statistics and definitions of variables

\begin{tabular}{|c|c|c|c|c|c|c|c|}
\hline Variable & Description & Source & Mean & St.dv & Min. & Max. & Obs. \\
\hline capstring & $\begin{array}{l}\text { Index of capital } \\
\text { requirement } \\
\text { stringency (higher } \\
\text { values indicate greater } \\
\text { stringency; range: } 0-7 \text { ) }\end{array}$ & $\begin{array}{l}\text { World } \\
\text { Bank }\end{array}$ & 5.160 & 1.330 & 2.000 & 7.000 & 436 \\
\hline cet1gov & $\begin{array}{l}\text { Capital instruments } \\
\text { eligible as CET1 capital } \\
\text { subscribed by } \\
\text { government on total } \\
\text { assets }\end{array}$ & ECB & 0.005 & 0.021 & 0.000 & 0.347 & 538 \\
\hline Ddom & $\begin{array}{l}\text { Dummy equal to } 1 \text { for } \\
\text { the home-country } \\
\text { credit portfolio, } 0 \text { for } \\
\text { the cross-border credit } \\
\text { portfolios }\end{array}$ & $\begin{array}{c}\text { Our } \\
\text { elaboration }\end{array}$ & - & - & - & - & - \\
\hline defrateCOR & $\begin{array}{l}\text { Corporate loan default } \\
\text { rate }\end{array}$ & EBA & 0.073 & 0.120 & 0.000 & 1.000 & 551 \\
\hline defrateINST & $\begin{array}{l}\text { Institutional loan } \\
\text { default rate }\end{array}$ & EBA & 0.003 & 0.017 & 0.000 & 0.175 & 586 \\
\hline defrateRET & Retail loan default rate & EBA & 0.074 & 0.131 & 0.000 & 1.000 & 473 \\
\hline defrateALL & $\begin{array}{l}\text { Default rate for the } \\
\text { overall credit } \\
\text { portfolio, equal to the } \\
\text { ratio between } \\
\text { defaulted and the sum } \\
\text { of defaulted and non- } \\
\text { defaulted loans }\end{array}$ & EBA & 0.045 & 0.072 & 0.000 & 0.499 & 589 \\
\hline Dhcet1 & $\begin{array}{l}\text { Dummy equal to } 1 \text { for } \\
\text { those banks with a } \\
\text { CET1 ratio bigger than } \\
\text { the third quartile of } \\
\text { the domestic } \\
\text { distribution, } 0 \\
\text { otherwise }\end{array}$ & $\begin{array}{c}\text { Our } \\
\text { elaboration }\end{array}$ & 0.402 & 0.491 & 0.000 & 1.000 & 627 \\
\hline Dhsup & $\begin{array}{l}\text { Dummy equal to } 1 \text { if } \\
\text { supind variable is } \\
\text { equal to the maximum } \\
\text { level (i.e. } 3 \text { ), } 0 \\
\text { otherwise }\end{array}$ & $\begin{array}{c}\text { Our } \\
\text { elaboration }\end{array}$ & 0.423 & 0.495 & 0.000 & 1.000 & 411 \\
\hline distance & $\begin{array}{l}\text { Latitude distance of } \\
\text { the home-country } \\
\text { from the equator }\end{array}$ & $\begin{array}{c}\text { Our } \\
\text { elaboration } \\
\text { on Google } \\
\text { Earth } \\
\end{array}$ & 0.547 & 0.064 & 0.390 & 0.688 & 595 \\
\hline DlegalFR & $\begin{array}{l}\text { Dummy equal to } 1 \text { if } \\
\text { the legal system of the } \\
\text { home-country is } \\
\text { French civil code, } 0 \\
\text { otherwise }\end{array}$ & $\begin{array}{l}\text { Barth, } \\
\text { Caprio and } \\
\text { Levine } \\
(2002)\end{array}$ & 0.388 & 0.488 & 0.000 & 1.000 & 595 \\
\hline DlegalGE & $\begin{array}{l}\text { Dummy equal to } 1 \text { if } \\
\text { the legal system of the } \\
\text { home-country is } \\
\text { German civil code, } 0\end{array}$ & $\begin{array}{l}\text { Barth, } \\
\text { Caprio and } \\
\text { Levine } \\
(2002)\end{array}$ & 0.427 & 0.495 & 0.000 & 1.000 & 595 \\
\hline
\end{tabular}




\begin{tabular}{|c|c|c|c|c|c|c|c|}
\hline & otherwise & & & & & & \\
\hline DlegalSC & $\begin{array}{l}\text { Dummy equal to } 1 \text { if } \\
\text { the legal system of the } \\
\text { home-country is } \\
\text { Scandinavian civil } \\
\text { code, } 0 \text { otherwise }\end{array}$ & $\begin{array}{l}\text { Barth, } \\
\text { Caprio and } \\
\text { Levine } \\
(2002)\end{array}$ & 0.101 & 0.301 & 0.000 & 1.000 & 595 \\
\hline DlegalUK & $\begin{array}{l}\text { Dummy equal to } 1 \text { if } \\
\text { the legal system of the } \\
\text { home-country is } \\
\text { English common law, } 0 \\
\text { otherwise }\end{array}$ & $\begin{array}{l}\text { Barth, } \\
\text { Caprio and } \\
\text { Levine } \\
(2002)\end{array}$ & 0.084 & 0.278 & 0.000 & 1.000 & 595 \\
\hline extaudit & $\begin{array}{l}\text { Index for the strength } \\
\text { of external audits } \\
\text { (higher values indicate } \\
\text { stronger audit; range: } \\
0-7 \text { ) }\end{array}$ & $\begin{array}{l}\text { World } \\
\text { Bank }\end{array}$ & 6.190 & 0.737 & 5.000 & 7.000 & 440 \\
\hline gdp & Real GDP growth rate & $\begin{array}{l}\text { World } \\
\text { Bank }\end{array}$ & -0.002 & 0.014 & -0.054 & 0.041 & 411 \\
\hline irbadvCOR & $\begin{array}{l}\text { Advanced IRB's use } \\
\text { intensity for } \\
\text { corporates }\end{array}$ & EBA & 0.293 & 0.399 & 0.000 & 1.000 & 551 \\
\hline irbadvINST & $\begin{array}{l}\text { Advanced IRB's use } \\
\text { intensity for } \\
\text { institutionals }\end{array}$ & EBA & 0.218 & 0.378 & 0.000 & 1.000 & 586 \\
\hline irbadvRET & $\begin{array}{l}\text { Advanced IRB's use } \\
\text { intensity for retails }\end{array}$ & EBA & 0.452 & 0.456 & 0.000 & 1.000 & 473 \\
\hline irbadvTOT & $\begin{array}{l}\text { Advanced IRB's use } \\
\text { intensity for the } \\
\text { overall credit portfolio }\end{array}$ & EBA & 0.325 & 0.391 & 0.000 & 1.000 & 589 \\
\hline irbCOR & $\begin{array}{l}\text { IRB's use intensity for } \\
\text { corporates }\end{array}$ & EBA & 0.550 & 0.425 & 0.000 & 1.000 & 551 \\
\hline irbfounCOR & $\begin{array}{l}\text { Foundation IRB's use } \\
\text { intensity for } \\
\text { corporates }\end{array}$ & EBA & 0.256 & 0.396 & 0.000 & 1.000 & 551 \\
\hline irbfounINST & $\begin{array}{l}\text { Foundation IRB's use } \\
\text { intensity for } \\
\text { institutionals }\end{array}$ & EBA & 0.233 & 0.400 & 0.000 & 1.000 & 586 \\
\hline irbfounRET & $\begin{array}{l}\text { Foundation IRB's use } \\
\text { intensity for retails }\end{array}$ & EBA & 0.014 & 0.107 & 0.000 & 0.931 & 473 \\
\hline irbfounALL & $\begin{array}{l}\text { Foundation IRB's use } \\
\text { intensity for the } \\
\text { overall credit portfolio }\end{array}$ & EBA & 0.200 & 0.351 & 0.000 & 1.000 & 589 \\
\hline irbINST & $\begin{array}{l}\text { IRB's use intensity for } \\
\text { institutionals }\end{array}$ & EBA & 0.451 & 0.458 & 0.000 & 1.000 & 586 \\
\hline irbRET & $\begin{array}{l}\text { IRB's use intensity for } \\
\text { retails }\end{array}$ & EBA & 0.466 & 0.455 & 0.000 & 1.000 & 473 \\
\hline irbALL & $\begin{array}{l}\text { IRB'S use intensity for } \\
\text { the overall credit } \\
\text { portfolio, equal to the } \\
\text { ratio between risk } \\
\text { unweighted exposures } \\
\text { evaluated with an IRB } \\
\text { approach (foundation } \\
\text { or advanced) and the } \\
\text { overall exposures }\end{array}$ & EBA & 0.525 & 0.431 & 0.000 & 1.000 & 589 \\
\hline
\end{tabular}




\begin{tabular}{|c|c|c|c|c|c|c|c|}
\hline lasset & $\begin{array}{l}\text { Natural log of total } \\
\text { assets }\end{array}$ & ECB & 11.400 & 1.430 & 6.340 & 14.300 & 538 \\
\hline levratio & $\begin{array}{l}\text { Leverage ratio } \\
\text { (common equity tier } 1 \\
\text { divided by total } \\
\text { exposure measure } \\
\text { according to Article } \\
429 \text { CRR) }\end{array}$ & ECB & 0.053 & 0.025 & 0.000 & 0.214 & 538 \\
\hline marketcap & $\begin{array}{l}\text { Stock exchange } \\
\text { market capitalization } \\
\text { over nominal GDP }\end{array}$ & $\begin{array}{l}\text { World } \\
\text { Bank }\end{array}$ & 0.588 & 0.313 & 0.039 & 1.280 & 411 \\
\hline markrisk & $\begin{array}{l}\text { Share of market risks } \\
\text { over the overall risk } \\
\text { weighted assets }\end{array}$ & EBA & 0.050 & 0.051 & 0.000 & 0.303 & 595 \\
\hline moralhaz & $\begin{array}{l}\text { Index for the degree } \\
\text { to which actions are } \\
\text { taken to mitigate } \\
\text { moral hazard (higher } \\
\text { values indicate } \\
\text { stronger actions; } \\
\text { range: } 0-3 \text { ) }\end{array}$ & $\begin{array}{l}\text { World } \\
\text { Bank }\end{array}$ & 1.330 & 0.762 & 0.000 & 3.000 & 440 \\
\hline muslim & $\begin{array}{l}\text { Percentage of Muslim } \\
\text { populations in the } \\
\text { home-country }\end{array}$ & $\begin{array}{c}\text { Pew } \\
\text { Research } \\
\text { Centre } \\
\end{array}$ & 5.250 & 3.540 & 0.100 & 25.300 & 595 \\
\hline provision & $\begin{array}{l}\text { Ratio between } \\
\text { impairment of non- } \\
\text { financial assets and } \\
\text { operating profit before } \\
\text { impairments }\end{array}$ & $\mathrm{ECB}$ & -0.079 & 0.388 & -8.030 & 0.155 & 595 \\
\hline riskdensityCOR & $\begin{array}{l}\text { Credit risk density for } \\
\text { corporate business } \\
\text { class }\end{array}$ & EBA & 0.696 & 0.254 & 0.165 & 1.430 & 540 \\
\hline riskdensityINST & $\begin{array}{l}\text { Credit risk density for } \\
\text { institutional business } \\
\text { class }\end{array}$ & EBA & 0.283 & 0.219 & 0.001 & 1.230 & 576 \\
\hline riskdensityRET & $\begin{array}{l}\text { Credit risk density for } \\
\text { retail business class }\end{array}$ & EBA & 0.403 & 0.205 & 0.019 & 0.975 & 462 \\
\hline riskdensityALL & $\begin{array}{l}\text { Risk density for the } \\
\text { overall non-defaulted } \\
\text { credit portfolio, equal } \\
\text { to risk exposure } \\
\text { amount on credit risk } \\
\text { over loans for non- } \\
\text { defaulted assets } \\
\end{array}$ & EBA & 0.439 & 0.224 & 0.031 & 1.010 & 579 \\
\hline roe & Return on equity & $\mathrm{ECB}$ & 0.000 & 0.004 & -0.024 & 0.054 & 595 \\
\hline supind & $\begin{array}{l}\text { Index of independence } \\
\text { of supervisory } \\
\text { authority (higher } \\
\text { values indicate greater } \\
\text { independence; range: } \\
0-3)\end{array}$ & $\begin{array}{l}\text { World } \\
\text { Bank }\end{array}$ & 2.130 & 0.837 & 1.000 & 3.000 & 411 \\
\hline
\end{tabular}

Notes: All data refer to 2013, with the exception of muslim that refer to 2010. 
Table 3. Correlation matrix

\begin{tabular}{|c|c|c|c|c|c|c|c|c|c|}
\hline & 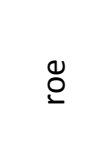 & $\begin{array}{l}\stackrel{0}{+0} \\
\stackrel{0}{0} \\
\underline{0}\end{array}$ & $\begin{array}{l}\text { Dे } \\
\text { a. } \\
\stackrel{ \pm}{0} \\
0\end{array}$ & 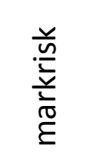 & $\begin{array}{l}\frac{c}{0} \\
\frac{0}{0} \\
\frac{0}{2}\end{array}$ & $\begin{array}{l}\vec{\Xi} \\
\widetilde{心} \\
\underline{\Xi}\end{array}$ & 음 & 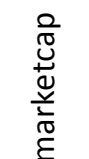 & 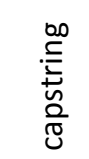 \\
\hline roe & 1.00 & & & & & & & & \\
\hline levratio & -0.03 & 1.00 & & & & & & & \\
\hline cet1gov & -0.20 & 0.33 & 1.00 & & & & & & \\
\hline markrisk & 0.03 & -0.39 & -0.08 & 1.00 & & & & & \\
\hline provision & 0.37 & -0.01 & -0.03 & 0.06 & 1.00 & & & & \\
\hline lasset & 0.07 & -0.37 & -0.09 & 0.39 & -0.01 & 1.00 & & & \\
\hline gdp & -0.01 & -0.10 & 0.02 & 0.07 & 0.10 & 0.07 & 1.00 & & \\
\hline marketcap & 0.07 & -0.11 & -0.05 & 0.08 & 0.08 & 0.10 & 0.50 & 1.00 & \\
\hline capstring & 0.06 & -0.03 & -0.02 & 0.03 & 0.04 & 0.03 & -0.08 & 0.32 & 1.00 \\
\hline supind & 0.05 & 0.06 & 0.03 & -0.04 & 0.01 & -0.01 & 0.02 & 0.27 & -0.18 \\
\hline defrateALL & -0.08 & 0.12 & 0.02 & -0.08 & -0.19 & 0.03 & -0.47 & -0.23 & 0.06 \\
\hline irbALL & 0.07 & -0.36 & -0.04 & 0.38 & 0.07 & 0.46 & 0.06 & 0.05 & -0.01 \\
\hline irbadvALL & 0.03 & -0.24 & -0.02 & 0.10 & 0.00 & 0.45 & 0.03 & 0.04 & 0.04 \\
\hline irbfounALL & 0.06 & -0.17 & -0.03 & 0.35 & 0.09 & 0.06 & 0.04 & 0.02 & -0.05 \\
\hline moralhaz & -0.02 & 0.02 & 0.03 & 0.00 & -0.03 & 0.05 & -0.02 & -0.28 & 0.33 \\
\hline extaudit & 0.00 & -0.07 & -0.08 & 0.04 & -0.03 & -0.02 & -0.14 & 0.09 & -0.08 \\
\hline
\end{tabular}

\begin{tabular}{|c|c|c|c|c|c|c|}
\hline & 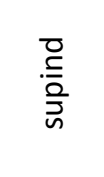 & 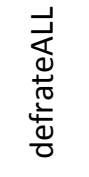 & 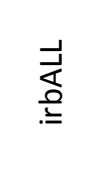 & 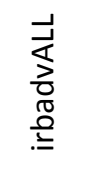 & 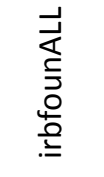 & 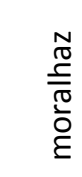 \\
\hline supind & 1.00 & & & & & \\
\hline defrateALL & -0.03 & 1.00 & & & & \\
\hline irbALL & 0.01 & -0.04 & 1.00 & & & \\
\hline irbadvALL & -0.02 & 0.11 & 0.61 & 1.00 & & \\
\hline irbfounALL & 0.03 & -0.16 & 0.52 & -0.36 & 1.00 & \\
\hline moralhaz & -0.32 & 0.02 & -0.01 & 0.05 & -0.06 & 1.00 \\
\hline extaudit & -0.53 & 0.15 & -0.01 & 0.01 & -0.02 & -0.44 \\
\hline
\end{tabular}

Notes: Bold correlations, in absolute term, higher than $60 \%$

Observations: 363 
Table 4. Regression results for the overall portfolio

The table reports the estimation of eq. (1) with respect to the overall portfolio.

\begin{tabular}{|c|c|c|c|c|}
\hline \multirow[b]{3}{*}{ Dependent var. } & \multicolumn{4}{|c|}{ Model } \\
\hline & 1 & II & III & IV \\
\hline & riskdensityALL & & riskdensityALL & \\
\hline \multirow[t]{2}{*}{ irbALL } & $-0.123 * * *$ & $-0.090 * *$ & $-0.116^{* * *}$ & - \\
\hline & [0.044] & {$[0.035]$} & [0.042] & \\
\hline \multirow[t]{2}{*}{ irbadvALL } & - & - & - & $-0.140 * * *$ \\
\hline & & & & [0.029] \\
\hline \multirow[t]{2}{*}{ irbfounALL } & - & - & - & -0.012 \\
\hline & & & & {$[0.056]$} \\
\hline \multirow[t]{2}{*}{ defrateALL } & $0.373^{* *}$ & $0.434^{* *}$ & $0.830 * * *$ & $0.471^{* * *}$ \\
\hline & {$[0.178]$} & {$[0.174]$} & [0.267] & [0.168] \\
\hline \multirow[t]{2}{*}{ provision } & - & $3.067^{* * *}$ & -0.154 & 0.244 \\
\hline & & [0.982] & [0.591] & {$[0.340]$} \\
\hline \multirow[t]{2}{*}{ levratio } & - & -0.164 & $3.037 * * *$ & $2.998 * * *$ \\
\hline & & {$[0.490]$} & [1.065] & [0.982] \\
\hline \multirow[t]{2}{*}{ cet1gov } & - & -0.164 & & -0.155 \\
\hline & & {$[0.490]$} & & {$[0.492]$} \\
\hline \multirow[t]{2}{*}{ markrisk } & - & 0.436 & $0.654^{* *}$ & 0.244 \\
\hline & & [0.287] & {$[0.313]$} & [0.340] \\
\hline \multirow[t]{2}{*}{ roe } & - & -2.122 & -2.065 & -2.299 \\
\hline & & {$[2.311]$} & [3.525] & {$[2.376]$} \\
\hline \multirow[t]{2}{*}{ lasset } & - & $0.296 * * *$ & $0.341^{* * *}$ & $0.211^{*}$ \\
\hline & & [0.108] & [0.123] & {$[0.116]$} \\
\hline \multirow[t]{2}{*}{ lasset2 } & - & $-0.012^{* * *}$ & $-0.014^{* * *}$ & -0.008 \\
\hline & & [0.005] & [0.005] & {$[0.005]$} \\
\hline \multirow[t]{2}{*}{ gdp } & - & - & -1.633 & - \\
\hline & & & [1.349] & \\
\hline \multirow[t]{2}{*}{ capstring } & - & - & $-0.015^{* * *}$ & - \\
\hline & & & [0.005] & \\
\hline \multirow[t]{2}{*}{ supind } & - & - & 0.015 & - \\
\hline & & & [0.017] & \\
\hline \multirow[t]{2}{*}{ moralhaz } & - & - & $0.044^{* * *}$ & - \\
\hline & & & [0.016] & \\
\hline \multirow[t]{2}{*}{ extaudit } & - & - & $0.070 * * *$ & - \\
\hline & & & [0.022] & \\
\hline \multirow[t]{2}{*}{ Ddom } & - & $-0.057^{* * *}$ & $-0.061 * * *$ & $-0.042 * *$ \\
\hline & & [0.021] & [0.020] & {$[0.021]$} \\
\hline \multirow[t]{2}{*}{ constant } & $0.466 * * *$ & $-1.538 * *$ & $-2.211 * * *$ & -1.100 \\
\hline & [0.038] & {$[0.646]$} & [0.778] & {$[0.689]$} \\
\hline Bank fixed effect & $\checkmark$ & - & - & - \\
\hline Country fixed effect & $\checkmark$ & $\checkmark$ & - & $\checkmark$ \\
\hline
\end{tabular}




\section{Wald test}

irbadvALL=irbfounALL

( $p$-value)

Overall R-squared

0.357

0.448

0.281

0.012

Number of banks

121

101

101

0.449

Obs.

579

499

363

101

Notes: Standard errors are clustered at bank level and appear in parentheses. We use Stata13 for all calculations.

$*, * *, * * *$ indicate statistical significance of the parameters at the $10 \%, 5 \%$ and $1 \%$ significance levels respectively. 
Table 5. Regression results by business sectors

The table reports the estimation of eq. (1) with respect to the corporate, retail and institutional sector. Dependent variable: riskdensityBS

\begin{tabular}{|c|c|c|c|}
\hline $\begin{array}{l}\text { Business sector } \\
\text { (BS) }\end{array}$ & $\begin{array}{c}\text { I } \\
\text { corporates } \\
\text { (COR) }\end{array}$ & $\begin{array}{l}\text { Model } \\
\text { II } \\
\text { retails } \\
\text { (RET) }\end{array}$ & $\begin{array}{c}\text { III } \\
\text { institutionals } \\
\text { (INST) }\end{array}$ \\
\hline \multirow[t]{2}{*}{ irbadvBS } & $-0.391 * * *$ & $-0.289 * * *$ & 0.050 \\
\hline & [0.043] & [0.023] & {$[0.041]$} \\
\hline \multirow[t]{2}{*}{ irbfounBS } & $-0.227 * * *$ & $-0.228 * * *$ & $0.118 * * *$ \\
\hline & {$[0.055]$} & [0.028] & {$[0.036]$} \\
\hline \multirow[t]{2}{*}{ defrateBS } & $0.272 * *$ & $0.166 * *$ & 0.659 \\
\hline & [0.134] & {$[0.077]$} & {$[0.742]$} \\
\hline \multirow[t]{2}{*}{ provision } & -0.004 & -0.009 & $-0.029 * * *$ \\
\hline & {$[0.016]$} & {$[0.013]$} & [0.009] \\
\hline \multirow[t]{2}{*}{ levratio } & $1.998 *$ & $2.936 * * *$ & $1.079 *$ \\
\hline & [1.051] & {$[0.547]$} & [0.573] \\
\hline \multirow[t]{2}{*}{ cet1gov } & -0.438 & $-0.767^{*}$ & 0.369 \\
\hline & {$[0.636]$} & [0.397] & [0.463] \\
\hline \multirow[t]{2}{*}{ markrisk } & -0.288 & 0.117 & -0.038 \\
\hline & [0.306] & [0.158] & [0.309] \\
\hline \multirow[t]{2}{*}{ roe } & $-4.380 * *$ & -0.738 & -0.093 \\
\hline & [2.143] & [2.176] & [1.664] \\
\hline \multirow[t]{2}{*}{ lasset } & 0.125 & -0.013 & -0.107 \\
\hline & [0.135] & [0.092] & [0.089] \\
\hline \multirow[t]{2}{*}{ lasset $^{2}$} & -0.004 & 0.001 & 0.004 \\
\hline & {$[0.006]$} & [0.004] & [0.004] \\
\hline \multirow[t]{2}{*}{ Ddom } & -0.038 & $-0.047 * * *$ & -0.020 \\
\hline & {$[0.025]$} & [0.013] & {$[0.022]$} \\
\hline \multirow[t]{2}{*}{ constant } & -0.129 & 0.338 & 0.793 \\
\hline & [0.816] & [0.542] & [0.516] \\
\hline Bank fixed effect & - & - & - \\
\hline Country fixed effect & $\checkmark$ & $\checkmark$ & $\checkmark$ \\
\hline $\begin{array}{l}\text { Wald test irbadv=irbfoun } \\
\text { ( } p \text {-value) }\end{array}$ & 0.001 & 0.003 & 0.138 \\
\hline Overall R-squared & 0.506 & 0.659 & 0.359 \\
\hline Number of banks & 99 & 96 & 101 \\
\hline Obs. & 462 & 384 & 496 \\
\hline
\end{tabular}

Notes: Standard errors are clustered at bank level and appear in parentheses. We use Stata13 for all calculations.

$*, * *, * * *$ indicate statistical significance of the parameters at the $10 \%, 5 \%$ and $1 \%$ significance levels respectively. 
Table 6. Regression results with interaction terms using country based credit portfolio data

The table reports the estimation of eq. (1) - with interaction terms for domestic banks (model I), level of independence of supervisor (model II) and level of capital ratio (model III)-based on the random-effect estimator.

Dependent variable: riskdensityALL

\begin{tabular}{|c|c|c|c|}
\hline $\begin{array}{l}\text { Business sector } \\
\text { (BS) }\end{array}$ & $\begin{array}{c}\text { I } \\
\text { overall portfolio } \\
(\mathrm{ALL})\end{array}$ & $\begin{array}{c}\text { Model } \\
\text { II } \\
\text { overall portfolio } \\
\text { (ALL) } \\
\end{array}$ & $\begin{array}{c}\text { III } \\
\text { overall portfolio } \\
(A L L)\end{array}$ \\
\hline \multirow[t]{2}{*}{ defrateALL×Ddom } & $0.494 *$ & - & - \\
\hline & {$[0.275]$} & & \\
\hline \multirow[t]{2}{*}{ defrateALL×(1-Ddom) } & $1.055^{* * *}$ & - & - \\
\hline & [0.368] & & \\
\hline \multirow[t]{2}{*}{ irbALL×Ddom } & $-0.221 * * *$ & - & - \\
\hline & [0.036] & & \\
\hline \multirow[t]{2}{*}{ irbALL×(1-Ddom) } & -0.074 & - & - \\
\hline & {$[0.051]$} & & \\
\hline \multirow[t]{2}{*}{ defrateALL×Dhsup } & - & $0.723^{* *}$ & - \\
\hline & & [0.333] & \\
\hline \multirow[t]{2}{*}{ defrateALL×(1-Dhsup) } & - & $0.929 * * *$ & - \\
\hline & & [0.283] & \\
\hline \multirow[t]{2}{*}{ irbALL×Dhsup } & - & -0.053 & - \\
\hline & & [0.049] & \\
\hline \multirow[t]{2}{*}{ irbALL×(1-Dhsup) } & - & $-0.165 * * *$ & - \\
\hline & & [0.043] & \\
\hline \multirow[t]{2}{*}{ defrateALL×Dhcet1 } & - & - & 0.770 \\
\hline & & & [0.485] \\
\hline \multirow[t]{2}{*}{ defrateALL×(1-Dhcet1) } & - & - & $0.809 * * *$ \\
\hline & & & {$[0.260]$} \\
\hline \multirow[t]{2}{*}{ irbALL×Dhcet1 } & - & - & $-0.174 * * *$ \\
\hline & & & {$[0.053]$} \\
\hline \multirow[t]{2}{*}{ irbALL×(1-Dhcet1) } & - & - & $-0.076 *$ \\
\hline & & & {$[0.046]$} \\
\hline \multirow[t]{2}{*}{ provision } & -0.015 & -0.012 & -0.016 \\
\hline & {$[0.016]$} & {$[0.015]$} & {$[0.015]$} \\
\hline \multirow[t]{2}{*}{ levratio } & $3.215^{* * *}$ & $3.073 * * *$ & $3.182 * * *$ \\
\hline & [1.051] & {$[1.070]$} & [1.091] \\
\hline \multirow[t]{2}{*}{ cet1gov } & -0.376 & -0.074 & -0.157 \\
\hline & [0.592] & {$[0.598]$} & {$[0.574]$} \\
\hline \multirow[t]{2}{*}{ markrisk } & $0.642 * *$ & $0.645^{* *}$ & $0.660 * *$ \\
\hline & [0.322] & [0.308] & [0.297] \\
\hline \multirow[t]{2}{*}{ roe } & -2.554 & -1.553 & -1.780 \\
\hline & [2.975] & [3.312] & [3.549] \\
\hline lasset & $0.316^{* *}$ & $0.350 * * *$ & $0.377 * * *$ \\
\hline
\end{tabular}




\begin{tabular}{|c|c|c|c|}
\hline & {$[0.128]$} & {$[0.124]$} & {$[0.127]$} \\
\hline \multirow[t]{2}{*}{ lasset $^{2}$} & $-0.013^{* *}$ & $-0.014 * * *$ & $-0.016^{* * *}$ \\
\hline & {$[0.005]$} & {$[0.005]$} & {$[0.005]$} \\
\hline \multirow[t]{2}{*}{ gdp } & -1.766 & -1.469 & -1.592 \\
\hline & {$[1.315]$} & {$[1.325]$} & [1.360] \\
\hline \multirow[t]{2}{*}{ capstring } & $-0.013 * *$ & $-0.012 * *$ & $-0.015 * * *$ \\
\hline & {$[0.005]$} & [0.006] & [0.005] \\
\hline \multirow[t]{2}{*}{ supind } & 0.018 & -0.005 & 0.015 \\
\hline & {$[0.016]$} & {$[0.018]$} & {$[0.017]$} \\
\hline \multirow[t]{2}{*}{ moralhaz } & $0.045^{* * *}$ & $0.042^{* *}$ & $0.047 * * *$ \\
\hline & {$[0.016]$} & {$[0.016]$} & [0.016] \\
\hline \multirow{2}{*}{ extaudit } & $0.072 * * *$ & $0.086 * * *$ & $0.072 * * *$ \\
\hline & {$[0.022]$} & {$[0.024]$} & {$[0.023]$} \\
\hline \multirow[t]{2}{*}{ Ddom } & 0.039 & $-0.059 * * *$ & $-0.060 * * *$ \\
\hline & {$[0.036]$} & [0.020] & {$[0.020]$} \\
\hline \multirow[t]{2}{*}{ constant } & $-2.132 * * *$ & $-2.330 * * *$ & $-2.405 * * *$ \\
\hline & [0.788] & [0.777] & [0.812] \\
\hline Bank fixed effect & - & - & - \\
\hline Country fixed effect & - & - & - \\
\hline \multicolumn{4}{|l|}{ Wald test (p-value) } \\
\hline defrateALL×Ddom=defrateALL×(1-Ddom) & 0.148 & - & - \\
\hline irbALL×Ddom=irbALL×(1-Ddom) & 0.004 & - & - \\
\hline defrateALL×Dhsup=defrateALL×(1-Dhsup) & - & 0.511 & - \\
\hline irbALL×Dhsup=irbALL×(1-Dhsup) & - & 0.002 & - \\
\hline defrateALL $\times$ Dhcet1 $=$ defrateALL $\times(1-D h c e t 1)$ & - & - & 0.930 \\
\hline irbALL×Dhcet1=irbALL×(1-Dhcet1) & - & - & 0.054 \\
\hline Overall R-squared & 0.301 & 0.295 & 0.299 \\
\hline Number of banks & 101 & 101 & 101 \\
\hline Obs. & 363 & 363 & 363 \\
\hline
\end{tabular}

Notes: Standard errors are clustered at bank level and appear in parentheses. We use Stata13 for all calculations. $*, * *, * * *$ indicate statistical significance of the parameters at the $10 \%, 5 \%$ and $1 \%$ significance levels respectively. 


\section{Table 7. Regression results with endogenous variables}

The table reports the estimation of eq. (1), with respect to the overall portfolio, corporate, retail and institutional sectors, based on the two-stage random-effect estimator. defrateBS, levratio, irbBS and roe are considered endogenous. As instrumental variables, in addition to the other covariates, we include DlegalUK, DlegalFR, DlegalDE and muslim in models (II) and (IV) and also distance in models (I) and (III).

Dependent variable: riskdensityBS

\begin{tabular}{|c|c|c|c|c|}
\hline \multirow[b]{2}{*}{ Business sector (BS) } & \multicolumn{4}{|c|}{ Model } \\
\hline & $\begin{array}{c}\text { I } \\
\text { overall } \\
\text { portfolio } \\
\text { (ALL) }\end{array}$ & $\begin{array}{c}\text { II } \\
\text { corporates } \\
\text { (COR) }\end{array}$ & $\begin{array}{l}\text { III } \\
\text { retails } \\
\text { (RET) }\end{array}$ & $\begin{array}{c}\text { IV } \\
\text { institutionals } \\
\text { (INST) }\end{array}$ \\
\hline \multirow[t]{2}{*}{ irbBS } & $-0.242 * *$ & $-0.333^{* *}$ & $-0.367 * * *$ & 0.023 \\
\hline & [0.109] & [0.165] & [0.085] & [0.123] \\
\hline \multirow[t]{2}{*}{ defrateBS } & -0.214 & 0.286 & -0.086 & 0.257 \\
\hline & {$[0.762]$} & [0.533] & [0.647] & [4.453] \\
\hline \multirow[t]{2}{*}{ provision } & 0.025 & $5.321 *$ & -0.483 & -0.344 \\
\hline & {$[0.038]$} & [2.938] & {$[0.755]$} & [0.463] \\
\hline \multirow[t]{2}{*}{ levratio } & $3.218^{*}$ & $5.321 *$ & 1.433 & -4.303 \\
\hline & [1.739] & [2.938] & [1.559] & {$[2.841]$} \\
\hline \multirow[t]{2}{*}{ cet1gov } & -0.623 & 0.194 & -6.020 & -0.029 \\
\hline & [0.721] & [0.693] & [5.691] & [0.149] \\
\hline \multirow[t]{2}{*}{ markrisk } & $0.845^{* * *}$ & 0.194 & 0.203 & -0.344 \\
\hline & [0.313] & [0.693] & {$[0.430]$} & [0.463] \\
\hline \multirow[t]{2}{*}{ roe } & $-17.631 * *$ & $-27.677 * *$ & -6.020 & -10.369 \\
\hline & [8.843] & {$[12.534]$} & [5.691] & {$[10.096]$} \\
\hline \multirow[t]{2}{*}{ lasset } & $0.388 * * *$ & $0.433^{* *}$ & -0.062 & -0.029 \\
\hline & {$[0.115]$} & [0.209] & {$[0.150]$} & [0.149] \\
\hline \multirow[t]{2}{*}{ lasset2 } & $-0.015^{* * *}$ & $-0.017 *$ & 0.003 & 0.001 \\
\hline & [0.005] & [0.009] & {$[0.006]$} & {$[0.006]$} \\
\hline \multirow[t]{2}{*}{ Ddom } & -0.016 & -0.022 & $-0.040 * *$ & -0.030 \\
\hline & [0.041] & [0.034] & [0.019] & [0.040] \\
\hline \multirow[t]{2}{*}{ gdp } & $-3.465 * *$ & -0.077 & -0.056 & $-6.112 * * *$ \\
\hline & [1.551] & [1.181] & {$[0.886]$} & [1.074] \\
\hline \multirow[t]{2}{*}{ capstring } & -0.012 & 0.013 & -0.002 & $-0.026 * * *$ \\
\hline & [0.010] & [0.010] & [0.006] & [0.009] \\
\hline \multirow[t]{2}{*}{ supind } & 0.033 & $0.056 * *$ & -0.021 & $0.040 *$ \\
\hline & [0.027] & [0.022] & [0.016] & [0.022] \\
\hline \multirow[t]{2}{*}{ moralhaz } & $0.055^{* *}$ & 0.029 & 0.014 & $0.065^{* * *}$ \\
\hline & {$[0.026]$} & {$[0.022]$} & [0.022] & {$[0.022]$} \\
\hline \multirow[t]{2}{*}{ extaudit } & $0.092 * * *$ & $0.057 * *$ & -0.022 & $0.065 * *$ \\
\hline & [0.034] & [0.027] & [0.017] & [0.027] \\
\hline \multirow[t]{2}{*}{ constant } & $-2.746 * * *$ & $-2.624 * *$ & 0.959 & 0.277 \\
\hline & {$[0.721]$} & [1.292] & [0.877] & [0.944] \\
\hline
\end{tabular}




\begin{tabular}{lcccc} 
Country fixed effect & - & - & - & - \\
\hline Overall R-squared & 0.164 & 0.355 & 0.635 & 0.064 \\
Sargan-Hansen statistic (p-value) & 0.509 & 0.357 & 0.499 & 0.256 \\
Number of banks & 101 & 99 & 93 & 101 \\
Obs & 363 & 345 & 281 & 361 \\
\hline
\end{tabular}

Notes: Standard errors are clustered at bank level and appear in parentheses. We use Stata13 for all calculations.

$*, * *, * * *$ indicate statistical significance of the parameters at the $10 \%, 5 \%$ and $1 \%$ significance levels respectively. 